—総 説 —

飼料の炭水化物成分の表現方法と牛用飼料の

簡易栄養価評価法

阿部亮

農林水産省畜産試験場，筑波農林研究団地 305

\title{
Analysis of the Carbohydrstes and Laboratory Methods for Predicting the Nutritive Value of Feeds for Cattle
}

\author{
Akira ABE \\ National Institute of Animal Industry \\ Tsukuba Norindanchi P. O. Box 5, Ibaraki-ken 305
}

はじめに

給与铜料の栄養佂を適切に把握するという事は家畜飼 蘶上の重要な一面であり，そのための方法としては家畜 を用いる消化試験法が中心に位置づけられる。しかし， この方法注一定の家畜頭数, 飼料, 労力, 誠瑍期間等定 必要と乙，その適用範囲はおのずから制限される。そこ で，それに代わるるのとしてょり籍易に栄養洒を推定す るための研究が促来より非常に多く蓄積されてきてい る. 本報告では，乙れらの研究成果を飼料の主な槛成成 分である炭水化物に中心を置いて整理したものである。

\section{1. 一般成分分析法にもとづく 栄養価評価法}

我が国のみならず，世界各国で最も広く用いられてい る飼料分析のシステム虫一般分析とも 6 成分分析と言 われているWeende system であり，乙れは飼料の炭水

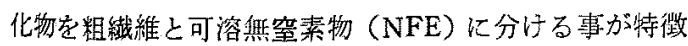
的な性質である. Weende system という名称诘粗繊維 定量の研究が行なわれたドイッの Weende Experimental Station にちなんで名付けられたものであり1，100 年以上の開，現在においてもなお広く用いられている方

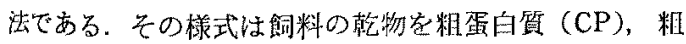

脂肪 (EE), NFE，粗㵶維 (CF) 拉よび灰分に分けるむ のであり，現在我が国において常法として用いられてい るものは森林・堀井ら ${ }^{2-5}$ 以上って改良された方法であ

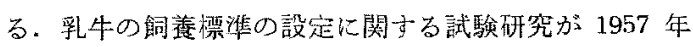

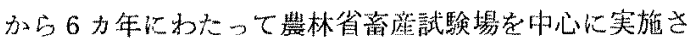
れたが，その㖄究の一環として一般成分分析法に基づく 地域的飼料の成分調査が行なわれ，成分含量と同時にそ の消化率，可消化䔄分総量（TDN）拉上び可消化粗蛋

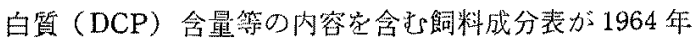
に刊行されているす い，各成分の含量と成分表中の消化率からその飼料の TDN，DCP 含量を知るといら方法が一般的に行なるれ るようになって来ている。

一方，消化率又性 TDN 合量学成分含量加ら統計的に 推定するという研究も数多い。

SCHNEIDER et al. ${ }^{7-10)}$ 依粗蛋白貿, 粗脂肪, NFE, 粗緎 維の会量から，こ机ら成分の消化豋ひいては TDN 含量 を求める算出式を生草, 乾草, サイレージ, 浱厚飼料別 に設定している. MEYER and LOFGREN ${ }^{11.122}$ は粗繊維含 量とTDN 含量との間に高い真の相関がある事を利用し て, 粗緒維含量加ら TDN 念量を推定する式をでルフ ルフフ乾草について提案している. 又, ADAMs et al. ${ }^{13,24)}$ は種々の粗飼料飞ついて, DONKER and NAIK ${ }^{15}$ はト 
ウモロコシサイレージとアルフォルフォ菓等を用いて数 瀻維之粗蛋白質の含量から TDN 含量它推定している，

NAGA and EL-SHAZLY ${ }^{16)}$ 住有機物 (OM) と粗蛋白質. 粗脂肪とから TDN 含量を推定可る方法の検討老们なっ

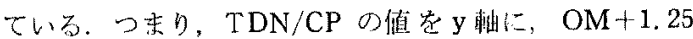

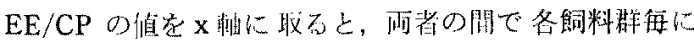
融い相関が認如られ，

$\mathrm{TDN}=\mathrm{a}(\mathrm{OM}+1.25 \mathrm{EE})+\mathrm{b} \cdot \mathrm{CP}$

の式が得られるしころから，各種牧草，飼料原料お゙よで

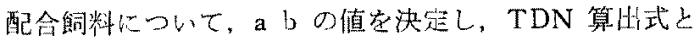
して提案している。

WALKER ${ }^{17)}$ は種々の乾草について，エネルギーの消化 染は粗繊維含量の增加にともなって直線的に減少する等

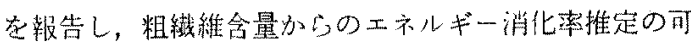
能性を示唆している，更に TDNのレベル越元て，代 謝エネルギー（ME）和よび正玙エネルギ一（NE）の含 量安一般成分分析值から知万らと方研究もなされてい

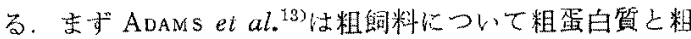
蟣維の含量から ME 龙放る式空報告しており，一方， DONKER and NAIK ${ }^{15}$ はトウモロコシサイレージとアルフ アルファ乾草定用いて，粗瀻維又は粗䄉維と蛋白質の含 量から NE (Estimated NE，ENE) 先推定与る式老提照 している. NeHRING et al. ${ }^{18} /$ 怯粗蛋白留, 粗脂肪, NFE 抢よび粗繊維の含量から試料の総エネルギー (GE) 合量 を，又これらの成分の可消化量加ら NEfat の含量它推 定する式究提案している。乳量と粗瀻維との関係につい

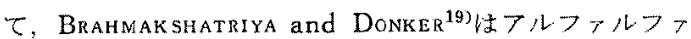
乾草とサイレージ給与の試験を行ない，粗瀻維の含量と 乳量との䦌に高い負の相関 $(\mathrm{r}=-0.95, \mathrm{P}<0.01)$ があ

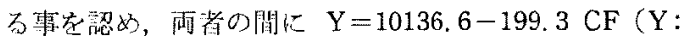
勫量. kg. $305 \mathrm{H}, 4 \%$ FCM) の回怊武老得ている.

以上のよう以一般成分の全罵から飼料の策等洒を推定 するための㮔々の办式が提案されてきているが，決め于

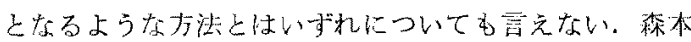

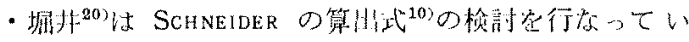

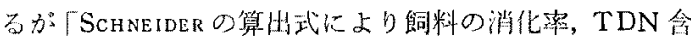

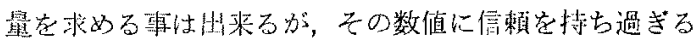

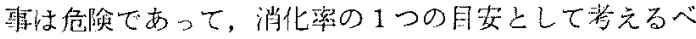
きであるう」と結び，石柴21はトウモロコシサイレージ について ADAMS 法 ${ }^{13}$ で得た TDN 含孯と in vivoでの 值が相違するという結果走示している。

速に MOHRENWISER ${ }^{22)}$ 仗アルファルファ乾草について ADAMs et al. $\sigma$ 方法 $^{13,14)}$ \& MEYER and LOFGREN 0 万

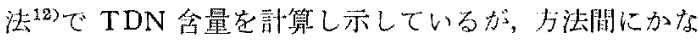
りの产が認められる。

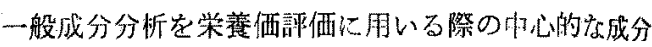
は粗瀻稚であるが,これはいずれの研究においてむTDN 含量を律速する指示物質として表現されている，例えば DONKER and NAIK の圪(5) (゙は, TDN=90.25-1.175 CF と記されている。つまり，粗蟣維含量が 1\%增加すると TDN 含量は $1.2 \%$ 減少するという意味である。

そこで問題となるのは，粗繊維は最良の指示物質で㘯 ろうか?，種↔の側面加ら見てその資格突備えているか という事である，具体的には，消化過程で栄養学的な特 異性を示すとか，又は飼料の種類を問わず，常化一定の 化学的性質を持っているか，というような事である，し かし，以下に述べるよらに粗緎維性必らずしもそのよう な個有の特質を持っているものではない，そこに，粗䋘 維含量に基づく栄萣価評洒法の限界が方るように思われ る.

\section{2. 一般成分分析の持つ欠陥とその改 良に関する研究}

一般成分分析において炭水化物分画を表現するの性 繊維乙 NFE の両成分であるが，これについて社栄養学 的な側面と化学的な側面からの不供が指摘されて来てい る、粗瀻維分析法が提案された当初，艺孔仿期料中の不

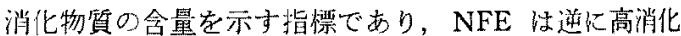

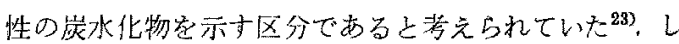
かしながら, CRAMPTON and MAYNARD ${ }^{24)}$ によって，反䨏 家畜の飼料では粗瀻維の方が NFEよりも高い消化㓡を

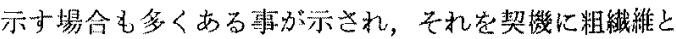
NFE の栄祀学的意義の不明膫さが問題点として大き くクロース゚アップされるようになった。一方，NORDFELDT et al. ${ }^{25}$ はセルロース，ペントサン拉よびリダニ ンタ゚一般分析では粗瀻維し NFE の两分西に跨って存在

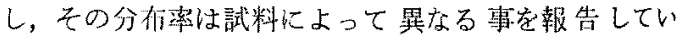
る. 化学分析がより笚一な成分への分画を指向寸当性質 のものであるとすれば，この事実は一般成分分析が炭水

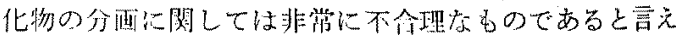
る。支た，一般分析の操作上，䌅，デンプンと言った炭水 化物は NFE 分画にはいる所方らら，NFE は可溶性の崖水 化物上後述するように不消化なりグニン，及び構造性炭 水化物の混而分西上いら性質のものになっている。1950

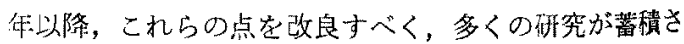
れてきているが，一貲している考え方は瀻維性の棈造性 炭水化物（セルロース，一ミセルロース）と非瀻維姓の 非嗨造性炭水化物（煻類，デンプン，フラクトサン)拉よ びリク゚ニンとに明確に分けて表現するという事である。

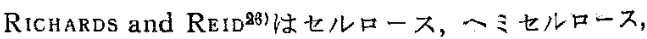


榶類，ペクチン，デンプンおよびリグニンを分析し，放 牧草てはリグニンは不消化であり，糖類は 99\%以上の 消化䛚であり，またセルロース，、ミ七ルロースは牧草 の生育時期の進展にともなってその消化乷が低下するこ とを示した上で，分析法としては粗䋐維の代わりにりグ シンを䇥量し，炭水化物は以下のようにして全炭水化物 の形でホす事定提案している。

全炭水化物 $=100 \%-(\mathrm{CP}+\mathrm{EE}+$ 粗灰分 + リ グニン

また ELY and MOORE ${ }^{27}$ 注構造性炭化物を木口セ儿 ロースとして定量し飼料成分は,

乾物二粗灰分，粗蛋白質，リグニン，フルコールベンゼ ソ抽出物，ホロセルロース，熱水抽出物 または

乾物二粗灰分，粗蛋白質，リグニン，アルコールベンゼ ン抽出物，ホ口セルロース，他の炭水化物 の形で装現古ること老提案している。

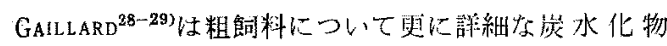

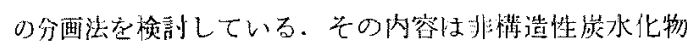
については単少楉数よフラタトサン荌分析し，一ミセル ロースについてむ KOHによる分画堂行ない，面にぺタ チン，セルロース，リグニンの定量法龙検討している.

また，笚少糖類はその消化率が $100 \%$ 示すとしてい $丂^{30)}$. WAITE and Gorrod ${ }^{31)}$, 扰よび WAITE et al. ${ }^{32)}$

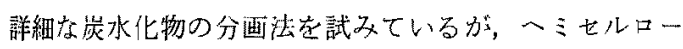
スオキシラン，アラバン，グルカン，ガラタタン执よび アルドビオン酸に分けて表示している。そして，ライグ ラスの場合，也ルロースと一ミセルロースの消化率は 刚の特点では差はないが，生育の進展にともなって一ミ セルロースの消化率がセルロースの消化率に比較して低 下する上いう結果宗しているる。

また DERIAZ $Z^{33}$ は日常分析に邀する方法として, シニ ウ酸フンモニウム, 希硫酸, $72 \%$ 硫酸の連続处理と比色 法によって, 可溶性桾類, ペントサン, 一キンサン,リ グニンの分别定量法を提供している。

一方，款類，配合跼料およびトウモロコシサイレージ などではデンプンの含量が非常に高い性質のるのである

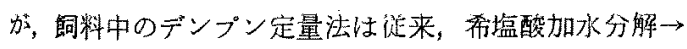
還元楉の定量 $\rightarrow$ 粗デンプンとしての表示といらシステ

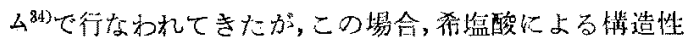
炭水化物由来の加水分解精の混入によるデンプンの過大

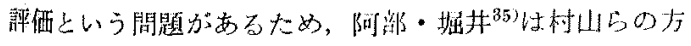

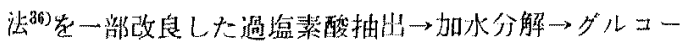
スオキシダーゼ此色のシステムを示した。 また, MACRAE et $a l$. $^{37}$ 牧草を用い種ヶのデンプン定量法についての 比較检愔を行なっている。
粗瀻維，NFE に代わる心゙き宸水化物の表現形式とし ては以上のような種々の方法が提案されているが，飼料 中の不消化部分の表現型として粗瀻維の代わりとリグニ ンを朋いているといらのが大きな特激である、リグニン 合量とTDN 含量との間には嗃い焦の相関が存在する12) 所から，リダニンを指示物質として策養洒の推定を行な

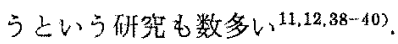

\section{3. 細胞膜物質と細胞内容物質への 分離, その方法と応用}

1960 年代の中頃迄见は上部したような炭水化物，リグ ニンについての系統的な分画法は一応完成されたが，こ の閒，乙れとは迎の傾庖の研究，つまり詳細な成分分析 をするのではなく，栄裳学的に類似した性質を持つ物質 群を1つの“かたまり”として把握していこうという動 きが同时に進行していた，具体的には飼料の乾物定細胞 膜物質 (CW) と細胞内谷物質 (CC) にまず分けるこ上

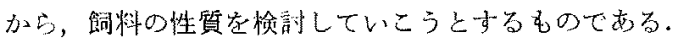

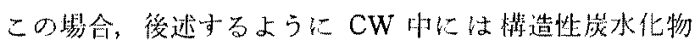
とリグニンが CC小には韭性造性炭水化物, 粗蛋白質, 粗脂肪が凷に含まれる。

訴料の乾物老 CCと CW とに分ける場合，㮔々の处

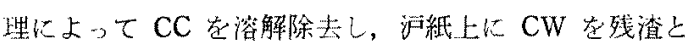
して得るという手法圭取るが，その祭りグニン，セルロ 一等の CW 成分を溶出することなく，加 CC 100

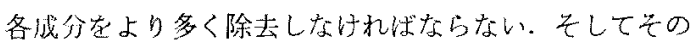
場合，粗蛋白筫茫いか心多く除去するかという事が毕大 の関心事になる，粗飼料の埸合，精など四溶性の炭水化 物怯之゙の上うな温和な処理でも簡単に溶出，除去され，

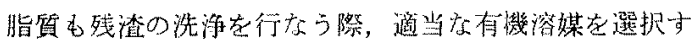
るこ上により問頟は解快するからである。したがって， CW の抽出・定量の研筧においては蛋白質の分解・除去 に何をどう用いるかが恶要なテーマになっている。その 手法上して史ず最初に完成されたのが界面活性用（デタ ージェント)在用いる方法である。

デタージェントは古くから蛋白質の変性・抽出威しし て朋いられ五ていたが, BEVENUE and WILLIAMS ${ }^{42)}$ は豆類 を材料として種ヶのデタージェントによる蛋白留の除去

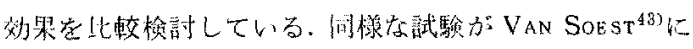
よっても行なわ扎ているが, VAN SOEST 恃蛋白質の除去 率の面加ら酸溶液とセチルトリメチルアンモニけムブロ

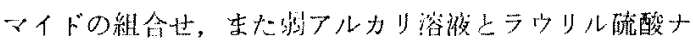
トリウムの維会せが效果的である事老推認し，ての知見 をもとに CW の定凬法它確立している

つ专り，陚料范ラウリル硫酸ナトリウム主主成分しし 


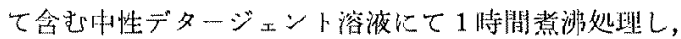
その残潜定 $\mathrm{CW}$ とするのであり, CC 含量は $100-\mathrm{CW}$ として求める.このようにして求められた $\mathrm{CW}$ の性質に 関しては, Colburn and Evans ${ }^{45)}$, 堀井・阿部(46), 更には BAILEY and ULYATT et al. ${ }^{47}$ が检部しているが, 堀步・阿

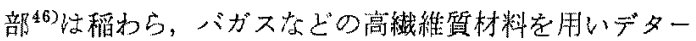
ジェント法によって得られた CWが棈造性炭水化物の研 究のための出発物質として適当であると泼告している.

便にVAN SOEST ${ }^{48)}$ はセチルトリメチルフンモニウムブ

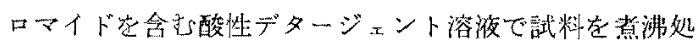
理して得られる残椬を Acid Detergent Fiber (ADF) とし，粗織維に代わる心゙るするして提案している。

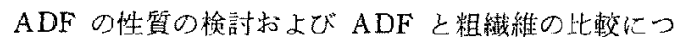
いては Colburn and Evans ${ }^{45)}$, Kim et al. ${ }^{49)}$, 堀执・俩

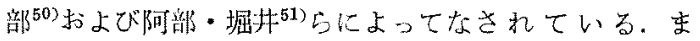
た，阿部・堀井 ${ }^{52}$ 汢人亦科乾草を朋い CW， ADF，七儿

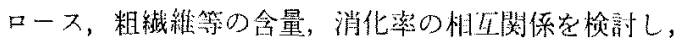

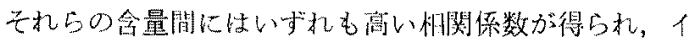

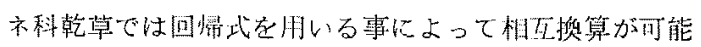

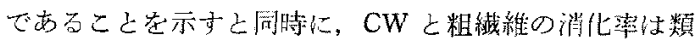
似すること省報告している。

現在，米国 NRC の飼料成分琵 ${ }^{539}$ に生粗䋐維の含量已 ともに, これらデタージェント分析による CW, ADF の 含量が示されている.

つい最近まで，CW の定量は一部の粗飼料に限定され ていた、デンブン客含けトウモロコシサイレージ,䩔類, 配合䣳籼ではデタージェントとの樂沸処理によりデンプ ンが糊化してコロイド状となり沪過不能となるためであ なた。かし阿部・堀井54および MCQUEEN and Nicho1. SON et al. ${ }^{55}$ 性，これらの試料についてもフミラーゼ前 処理を施こすことによって CW 定冨定可能とし，デタ ージェント分析の適用䈱囲を拡大した.

一方，CW の抽出・定量に関してデタージェント以外

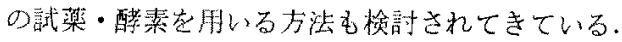

$\operatorname{MOIR}^{56.67)}$ はペプシン溶液 $\rightarrow$ タ人一ル抽出 $\rightarrow$ エ-テ ル抽出 $\rightarrow$ 熱水又はシュウ酸アンモニウム溶液抽出のシス テム在提案して和り，また篓地 $5^{58}$ 《脱脂大豆の $\mathrm{CW}$ 抽 出に蛋白質分解醉䋕のプロナーゼ朋いている、 $\mathrm{ABE}$

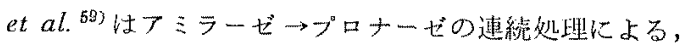

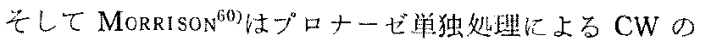

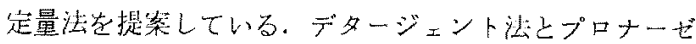
法との比較については，蛋白質の除去搳の面からみると

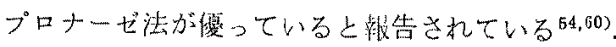

$\mathrm{CC}$ ¿ CW の分離法については以上のようであるが， VAN SOEST ${ }^{61)}$ はデタージェント法によって求めた CC と

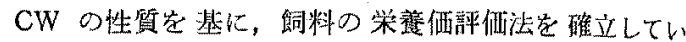

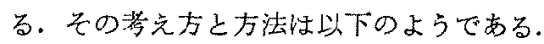

ます”，両分西の化学的内容について CC 性䋨類，フラ クトサン等の可溶性炭水化物，デンプンペクチン，非 蛋白態空素化合物，蛋白質，脂質技よびその他の可溶物 筫とから成り，CW は一ミセルロース，七ルロース，リ グニンおよび熱損傷老受けた蛋白質から成ると規定し， 多くの試料について両分画の栄意的な均一性を調查して いる。その結果，CC はその乾物中の含量と in vivoの 消化試驗で得られる可消化县之の間には非常に高い相関 係数 $(\mathrm{r}=0.99, \mathrm{P}<0.01)$ が得られ，乙の分画が栄堂的 な均一性它持つるのであること学確認し， $\mathrm{CC}$ の含量 $(\mathrm{x})$ 七可消化量 $(\mathrm{y})$ との間に $\mathrm{y}=0.98 \mathrm{x}-12.9$ の回渌式を得 ると同㭙に，この式から CC 分画の真の消化率は100\% に近い $(98 \%)$ としてる。また，CW は CC と翼なっ て含量と可消化量との間には高い相関係数が得られず， 栄養的な均一性を持つと仙言えなかったが，CW の消化

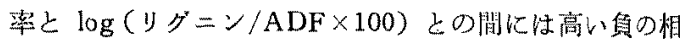
関俰数 $(\mathrm{r}=-0.98, \mathrm{P}<0.01)$ 芳得ら机るところから， $\mathrm{ADF}$ とりダニンの含量を測定することにより，CWの

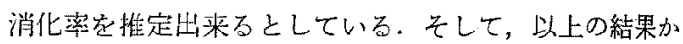

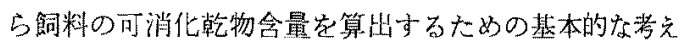
方を以下の式で示している。

可消化乾物 $=$ 可消化 $\mathrm{CC}+$ 可消化 $\mathrm{CW}$

$$
\begin{aligned}
= & 0.98 \mathrm{CC}+\mathrm{CW}[147.3-78.9 \times \log (1) \mathscr{} \\
& =\forall / \mathrm{ADF} \times 100)]-12.9
\end{aligned}
$$

里にこの式で求められた值に刘してケイ酸の補正和积 よび ADF 中の窒素補正68)を行なって最終的な值を得る というものであり, これはデタージェント分析の方法と ともに普及版 ${ }^{64}$ によめられている。

また，Minson ${ }^{65}$ は同様の考它方多多くの暖地型牧草 に適用し，有機物消化率推定の回㷌式学設定し，その 式から得られた值と, in vivo の有機物消化率々の間 $k r=0.93(P<0.001)$ の高い相関俰数を得ている.

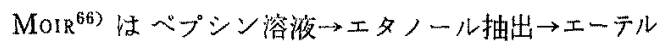
抽出 $\rightarrow$ 熱水又はシュウ酸アンモニウム溶液抽出で得た $\mathrm{CW}$ と粗蛩白質とから，可消化有機物含量を推定し，36 点のイネ科，マメ科の牧草に招いて in vivo との間に $r=0.912(\mathrm{P}<0.01, \operatorname{RSD} 3.18)$ の絬果等得てい子.

\section{4. ルーメン内容液を利用する in vitro 人工消化試験}

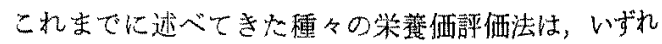
も化学的な手法によって得られた歲分の性質と、統計如 理定かみ合せた推定法である。 


\section{牛用䝭料の栄養仙評価法}

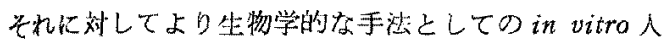
工消化試験法が同時に古くから検討されてきている.

フィステル装着の反㑼家畜から第 1 鼠内容液を採取 し，一定の姏理を施した上で検体試料它添加し，第 1 冒 内と似大環境条件（程類濃度， $\mathrm{pH}$, 温度, 熑気性の維持 等)の下で培養し，そこで得られた乾物，有機物等の消 失率 in vitro の消化率とす尚ものである。

in vitro のルーメンジェース法は 1950 年の初期から 中期にがて Bentley, Johnson et al $の$ Ohio Agric. Exp. St. のグループによって精力的にその研究が 展 開

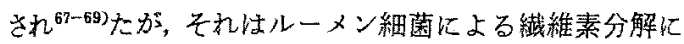
関しての基礎的な研究が主であり，直挼飼料の栄意価評 価法に結びっくものではなかっったが，繊維素分解性菌の 栄養要求の解明なよ゙，栄養価誰価法に刘しての基礎的な 知見が集積されたと言ってよいであるう。

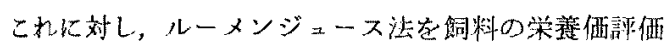
の目的に沿って簡素化し，実験室で日常的に利朋出来る 方法としたのは TILLEY and TERRY ${ }^{70)}$ の研究である。こ 札第 1 段階のルーメンジュース培䓹, 第 2 段階のペプ シン好理から棈成されているが，第 1 段階のルーメンジ ュース培養に括いてブンゼンバルブを利用するなど，良 来の in vitro 法を大湢に簡素化し，一度に多数の試料を 処理し得る方法とし，牧草の栄養性育種の研究に刘して 強力な手法を提供することとなった。 その後, DENT ${ }^{71)}$, ROGers and Whitemore ${ }^{72)}$, AleXander and MCGowan ${ }^{73}$ および Minson and MCLEOD ${ }^{74)}$ et al. Kよって種々の改 良が加えられてきている。最近，OSBOURN and TERRY は牧草の in vitro 法についてのレビューを行なっている ので参照されたい.

このほか, in vitro 法は多方面に用いられているが， ALEXANDER and MCGOWAN ${ }^{76)}$ 抢よひ SCHMID et al. ${ }^{77} \mathrm{~K}^{2}$ ってサイレージに刘しての利用も検討されている。

また，条野・西松 ${ }^{78)}$ および KUMENo et al. ${ }^{793}$ らは濃厚 飼料人の in vitro 法の遙用老試み, in vitro の乾物消化 率と in vivo の乾物, NFE, 有機物の消化染就よ゙ TDN 含量との間には有意な相関がある事党認めている ${ }^{78)}$.

これらの研究と同時に，構造性㟶水化物の評価を行な 5手段としても in vitro 法が用いられている. SMITH et $a l^{800}$ はチモシ一, アルフフルファなど定用いそのCW のルーメン細菌による分解過程を in vitroに追跡し，そ の消化は 1 次反志で進行与ること，またその消化速度は 陚料によって異なる事定明らかにし，消化速度とリグ二 ンとの関係についても検討している。をた，阿部・班

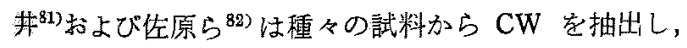
その標品崖 in vitro 消化試験に供試し, CW OPoten- tial Availability 0 比較も行なっている. CARLIER et al. 83)はデタージェント法での CW の in vitro 消化率と in vivo の消化率の間には非常に高い相関係数が得られ るところから，CW の栄養価評価法として in vitro 消化 試験が有効であるとしている。

更に, 牧草の刚取時期と栄意価の変化孝 in vitro 汒に よって追跡する研究が TILLEY et $a l^{84)}$, 岡本・広瀬 ${ }^{85}$ ら によって行なかれ，また MowaT et al. ${ }^{86)}$ 注リグニン会

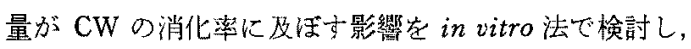
乾物中のリグニン含量と $\mathrm{CW} の$ in vitro 消化率の間に 急の相関があり，そしてそれはイネ科牧草に顯著である と報告している，岡本・広瀬 ${ }^{872}$ は牧草の消化に及ほすリ グニンの影䋨を検討するため，脱リグニン試料，リグニ ン添加試料の in vitro 消化試験安行ない構造性炭水化物

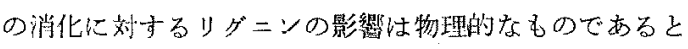
している.

リグニン以外にす $\mathrm{CW}$ の消化定規制する砍网は考元 られるが，その1つとして䉟造性炭水化物自体の結晶性 の程度があげられる ${ }^{88)}$ 。

この要因の影悢についてもin vitro注が利朋され ${ }^{88-90)}$,

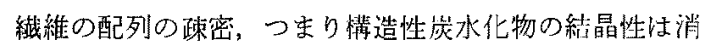
化の初期反应速度を律速する事が報告 ${ }^{89-90) さ れ て い る 。 ~}$

in vitro のルーメンジェース法は以上の様に多面的な 利用性を持ち，から反第家畜の消化過程の一部安なぞっ ている有用な方法では方が，反面，反罚家畜へのフィ ステルの装着执よびその維持，更には培養中の熑気性の 維持など操作上の䙅雑さなどを考慮すると，艺の適用筑 囲は限られるという性筫を恃つ方法であるう。

\section{5. セルラーゼの利用}

牧草を例にとって，ての in vitro 消化における物質の 分解様式を考党て友ると，それは(1)可溶性炭水化物，非 蛋白態窒素化合物，その他の可溶物の液層入の单純な移 行，第 1 胃内細囷以上当(2)蛋白質の分解，(3)棈造性炭水 化物の分解，上ふ心成号と考光られる。

粗飼料の場合には(3)の部分が重要な位置を与めている 事は周知の事実である。構造性炭水化物の分解仕第 1 胃 内細藏のセルラーセ，一ミセルラーゼによって应机る

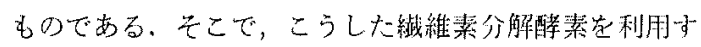

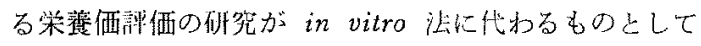
DONEFER et $a l .{ }^{91}$ 以来, 積極的に展開されてきている.

用いられてい名醉素はせルラービであるか，これは多 くの場合人ミセルラーゼ活性苍も含む，いわゆる粗酵惄 標品である.女ルラーゼの微生物オリジンとその分解力 の比較については JONES and HAYWARD ${ }^{22)}, C_{\text {LARK }}$ and 
BEARD ${ }^{933}$, Rexi: ${ }^{94)}$ 扩よび McQueen and VAN Soest $e t$ $a l .{ }^{95}$ によって検討されているが，現在，最むよく月いら れているのは Trichoderma セルラーゼである.

棈造性炭水化物の分解及応につき，セルラーゼとin vivo ないしは in vitro 沠との比較, 检討がなされ机

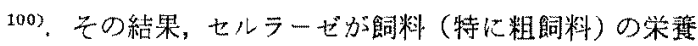
価啸洒に利朋壮来るという事が確綛されるに到ってい る。それらの知見を背景としてせルラーセ㚭理を中心と した種々の評価法が提案されているが，それ整理する と以下のようである。

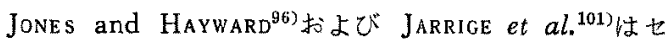
ルラーゼ溶液のみでの処理法を提案し, JONES and HAYWARD $^{90)}$ はこの万法で得られた乾物分解率之in vivoの畭

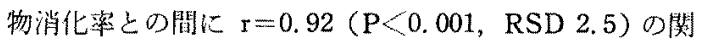
倸が得られ，かつ非常以留易であるところから，牧草の 栄滇性育偅の際のスクリーニングテストに適するとして W.

また, Jones and Haywaro ${ }^{92)}$, Clark and Beard ${ }^{93}$,

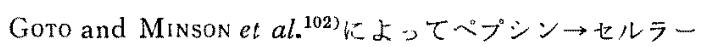
ゼの連続処理法必恰討され，阿部ら ${ }^{103-104)}$ によって熱 水 $\rightarrow$ セラーゼおよび亚硫酸ナトリウム 等の二段解法が検討されている。

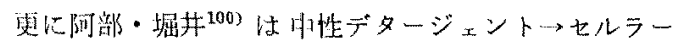
セ゚の連続処埋システムを試み，多くの牧乾草で連稑仙理 によって得られる乾物分解率と in vivo の乾物消化率拉 上び TDN 含量との間に當い相關が得られる事を報管 している.

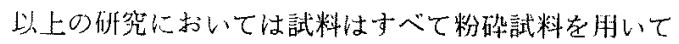

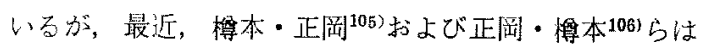
米粉砕の新鮮葉心㨁接セルラーゼ処理を施こす簡易法の 檢討它行店っている。

一方，牧草以外の材料に刘してのセルラーゼ法の利用 も行なるれているが，それは主に低品質粗飼料に対して のものであり，具体例としては REXEN ${ }^{94)}$, GugGoLTZ el

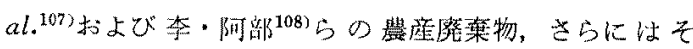

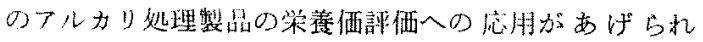
万.

せルラーゼ利用に祭しての手汒については以上の症で

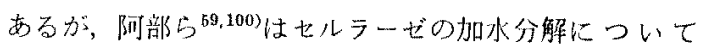

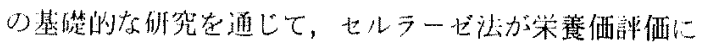
際して有效である事への理䜽的根拠を与えている。

まザセルラーセ゚による CW の份解反杣は速度定数の

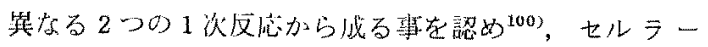
ゼによって短恃閒（4恃間）に分解される CW 都分（a

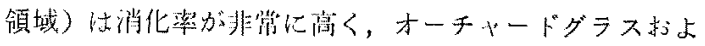

びオーチャードダラス主体の乾草 (8 点)では，ての消 化率は平均值で 96.5\%, アルファルフォ乾草 $(6$ 点)で 怯 $91.5 \%$ 値宗示す。

䦽に，セルラーセに不溶の残澘 (b-領域) の平均消化

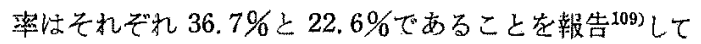
いる，つ来り，CWはセルラーゼ分解によって高消化率 の区分 (a) と低消化率の区分（b）とに分蜼することが 出来, b 含量と CW 消化率の間には乾草の場合, 高い 顀の相関 $(\mathrm{r}=-0.919, \mathrm{P}<0.01)^{59}$ が得られるとこらか ら, a の含量が威少しbの含量が橧加するにつれて $\mathrm{cW}$ の消化渠が低下すること省明らかにしている。

阿部ら ${ }^{59.107)}$ は更に，七ルラーゼでの処理を中心にす えた酵素分析のシステムを提案しているが，こ机はアミ ラーゼープロナーゼの炕理で陚料の有機物をまず CCと $\mathrm{CW}$ とに分け, 次に $\mathrm{CW}$ をんラーゼ处理によって、分 画とb分画とに分けるものである.

VAN SOEST ${ }^{\mathrm{i} 11}$ はデータジェント法によって得られた

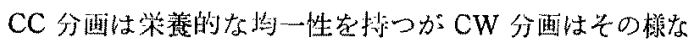

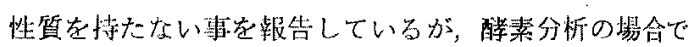

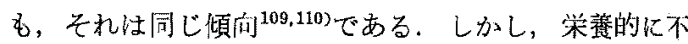

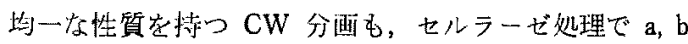

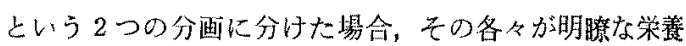
的出一性を示すことがイネ科乾草およびトウモロコシサ イレージで立証されている109,110\}.

更に CC，a，b の栄養的均一性它利用して，同消化有 機物の含量を酥素分析によって推立する事も併世て検討 されている10\%。

\section{6. 種々の方法間の比較・検討}

以上，理々の栄竟価評価法についての紹介茟行なって きたが，どの方法艺用いるかは，精度，試娩の目的，設 備, 労力等, 総合的に判断して决められることになるで あるう。

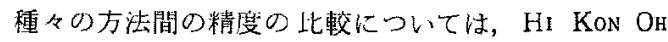
and Baumgardi ${ }^{111}$, Tinnimit and Thomas ${ }^{112}$, McLeod and Minson ${ }^{113)}$, AERTS et al. ${ }^{114)}$ 斿よび堤・阿部ら ${ }^{1157} \mathrm{~K}$ よって検討されている.この中で, AERTs et al.111)の研 究の規模が最も大きい,つまり，42点のイ科乾草，56 点のサイレージおよび 39 点のペレットを供試し，種々 の成分表の消化率の利般成分分析の成分からの栄 㴽価誂価，デタージェント分析による各成分の利用によ

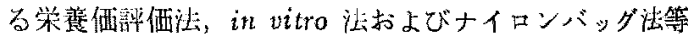
について，此校検討し，各々の方法での有機物消化率と in vivo 有機物消化率の相関俰数, 回归式等が飼料群每 佂されている。 


\section{牛用䝭料の栄筈価評醉法}

$$
\text { おわりに }
$$

試料の化学分析法と栄養価評洒に関する研究は，より 化学的な合理性と簡素化索目ざして進展してきてはいる が，英して完成された方法が提供されているわけではな 以.

したがって，栄養価被洒法に関して言うならば当面は 推定誤差をより小さくしていく努力が今後とも緙けられ ねばならないであろうし，そのためには既存の方法の改 良と，新しい手法の開発が積極的に行なわれるべきであ ちう.

\section{文献}

1) Weinstock, A. and G. H. Benham, Cereal Chem., 28: 490-497. 1950.

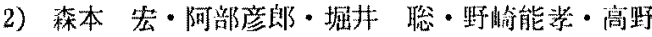
一雄・平野昌三・野辺田清，㟽技研朝告，G 16: 1-18. 1959.

3）森本 公・堀井 瞈・吉目 実・田山孝之助・小 松昌義，農技研報告，G 19：143-152，1960.

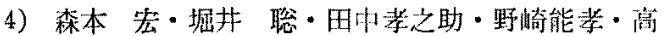

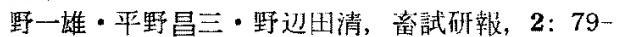
86. 1963

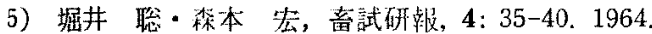

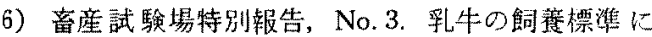
関する研究，IV，地域的飼料の成分開查成蛽， 1964.

7) Schneider, B. H., H. L. Lucas, H. M. Pavlec, and M. A. Cipolloni, J. Anim. Sci., 9: 373379. 1950 .

8) Schnetder, B. H. and H. L. Lucas, J. Anim. Sci., 9: 504-512. 1950.

9) Schneider, B. H., H. L. Lucas., H. M. Pavlech and M. A. Cipolloni, J. Anim. Sci,, 10: 706713. 1951

10) Schneider, B. H., H. L. Lucas., M. A. Cipolloni and H. M. PAVlech, J. Anim. Sci., 11: 77-83. 1952.

11) Meyer, J.H. and G. P. Lofgreen, J. Anim. Sci., 15: 543-549. 1956.

12) Meyer, J.H. and G. P. Lofgreen, J. Anim. Sci, 18: 1233-1242. 1959.

13) Adams, R. S., J. Dairy Sci,, 44: 2105-2112. 1961.

14) Adams, R. S., J. H. Moore, E. M. Kesler and G. Z. Stevens, J. Dairy Sci, 47: 1461, 1964.

15) Donker, J. D. and D. G. NaIK, J. Dairy Sci., 62: 424-432. 1979

16) NagA, M. A. and K. EL-Shazly, J. Agric. Sci, 77: 25-31. 1971 .

17) WALKER, D. M. and W. R. HEPBURN, J. Agric. Sci., 45: 298-310. 1955.
18) Nehring, K, and G. F. W. Haenlian, J. Anim. Sci, 36: 949-964. 1973.

19) Brahmakshatriya, R. D. and J. D. Donker, J. Dairy Sci., 53: 680, 1970.

20）森本 去・堀开 聡，窗試研郝，2：69-78，1963.

21）石栗御機，新得畜試研被，3:1-12，1972.

22) Mohrenweiser, H. W. and J.H. Donker, J. Dairy Sci., 51: 373-377. 1968.

23) Van Soest, P.J., J. Assoc. Off. Anal. Chem., 49: 546-551. 1966.

24) Crampton, E. W. and L. A. Maynard, J. Nutr., 15: 383-395, 1938.

25) Nordfeldt, S., O. Svanberg and O. Claesson, Acta. Agr. Suecana, 3: 135-177. 1949.

26) Richards, C. R. and J. T. Reid, J. Dairy Sci., 36: 1006-1015. 1953.

27) Ely, R. E. and L. A. Moore, J. Anim. Sci,, 14 718-724. 1955.

28) Galllard, B. D. E., J. Sci. Fd. Agric., 9: 170177. 1958.

29) Galllard, B. D.E;, J. Sci. Fd. Agric., 9: 346353. 1958.

30) Gaillard, B. D. E., J. Agric, Sci,, 59:369-373. 1962.

31) Waite, R. and A. R. N. Gorrod, J. Sci. Fd. Agric, 10: 308-317. 1959.

32) Waite, R., M. J. Johnson and D. G. Armstrong, J. Agric. Sci., 62: 391-398. 1964.

33) Deriaz, R. E., J. Sci. Fd. Agric., 12; 152-160. 1961.

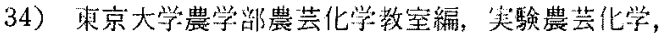
上替, 131. 朝爷害店. 果京. 1962 .

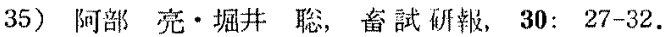
1976.

36）村山 登・吉野 実・大島正男・场原貞雄・川原 崎裕司，農技研報告，B 4：123-165，1955.

37) Macrae, J.C., D. Smith and R. M. McCready, J. Sci. Fd. Agric., 25: 1465-1469. 1974.

38) Forbes, R. M. and W.P. Garrigus, J. Anim. Sci., 9: 354-362. 1950.

39) Laube, W., Arch. Tierernähr. 10: 99-112. 1960.

40) Morrison, I. M., J. Br. Grassld. Soc., 28 : 153154. 1973.

41) Forster, J. F., J. T. Yang and N. H. Yui, Cereal Chem., 477-487. 1950.

42) Bevenue, A. and K. T. Wiliams, J. Assoc. Off. Anal. Chem., 42: 441-444, 1959.

43) Van Soest, P. J., J. Asooc. Off. Anal. Chem., 46: 825-829. 1963.

44) VAN Soest, P. J. and R. H. Wine, J. Assoc. Off. Anal. Chem., 50: 50-55. 1967.

45) Colburn, M. W. and J. L. Evans, J. Dairy Sci, 50: 1130-1135. 1967.

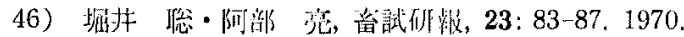


47) Batley, R. W. and M. J. Ulyatt, N. Z. J. Agric. Res., 13: 591-604. 1970.

48) Van Soest, P. J., J. Assoc. Off. Anal. Chem. 46: 829-835, 1963.

49) Kim, J. T., J. T. Gillingham and C. B. LoadHoL T, J. Assoc. Off. Anal. Chem., 50; 340-343. 1967.

50）堀材 聡-阿部 克, 音試研趣, 25: 63-68, 1972.

51）阿部 亮・堀井 聡，蓄試研報，27：1-4. 1973.

52）阿部 亮・堀井 聡, 音試研㪕, 25: 69-74。1972.

53) National Research Council, Nutrient requirement of dairy cattle, National Academy Science, Washington D.C. 1978.

54) 阿部 亮・堀井 聡, 日草誌, 25：70-75. 1979.

55) McQueen, R. E. and J. W. G. Nichol son, J. Assoc. Off. Anal. Chem., 62: 676-680. 1979.

56) Morr, K. W., J. Sci. Fd. Agric., 22: 338-341. 1971.

57) Molr, K. W., J. Agric. Sci, 78: 351-353. 1972 .

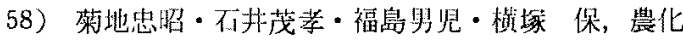
誌, 45：228-234. 1971.

59) Авe, A., S. Horil and K. Kameoka, J. Anim. Sci., 46: 1483-1490, 1979.

60) Morrison, I. M., J. Agric. Sci., 80: 407-410. 1973.

61) Van Soest, P. J., J. Anim. Sci., 26:119-128. 1967.

62) Van Soest, P. J. and L. H. P. Jones, J. Dairy Sci., 51: 1644-1648. 1968.

63) Van Soest, P. J., J. Assoc. Off. Anal. Chem., 48: 785-790, 1965.

64) Goering, H. K. and P. J. Van Soest, Forage fiber analysis, Agriculture handbook No. 379. U.S. D. A. Washington D.C. 1970.

65) Minson, D. J., Aust. J. Agric. Res., 22: 589 598. 1971.

66) Morn, K. W., J. Agric. Sci,, 78: 355-362. 1972.

67) Bentley, O. G., R. R. Johnson, T. V. Hershberger, J.H. Cline and A. L. Moxon, J. Nutr., 57: 389-399. 1955.

68) Bentley, O. G., A. Latona, P. De Paul and C. H. Hunt, J. Anim. Sci., 10: 1038. 1951.

69) Bentley, O. G., R. R. Johnson, S. Vanecko and C. H. Hunt, J. Anim. Sci., 13: 581-593, 1954.

70) Tilley, J. M. A. and R. A. Terry, J. Br. Grassld. Soc. 18: 104-111, 1963.

71) Dent, J. W., J. Br. Grassld. Soc. 18: 181-188. 1963.

72) Rogers, H. H. and E. T. Whitmore, J. Br. Grassld. Soc., 21: 150-152. 1966.

73) Alexander, R. H. and M. McGowan, J. Br. Grassld. Soc., 21: 140-147, 1966.

74) Minson, D. J. and M. N. McLeod, Technical
Faper, Division of Tropical Pastures, CSIRO Australia No. 8: 15. 1972.

75) Osbourn, D. F. and R. A. Terry, Proc. Nutr. Soc., 36: 219-225. 1977.

76) Alexander, R. H. and M. McGowan, J. Br. Grassld. Soc., 24: 195-198. 1969.

77) Schmid, A. R., R. D. Goodrich, G. C. Marten, J. C. Meiske, R. M. Jordan and J. L. Halgerson, Agron. J., 67: 243-246. 1975.

78）策野文雄・西松一郎，日畜会派，39：162-167。 1967.

79) Kumeno, F., B. A. Dehority and R. R. Johnson, J. Anim. Sci, 26: 867-871. 1967.

80) Smith, L. W., H. K. Goering, D. R. Waldo and C. H. Gordon, J. Dairy Sci., 54: 71-76, 1971.

81）阿部亮・堀井聡，日畜会報，49：733-738, 1978.

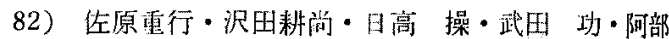
宽，日草誌，24：345-352，1979.

83) Carlier, L. A., B. G. Cottyn and J. V. Aerts, Anim. Feed Science and Technology, 1: 607617. 1976.

84) Tilley, J.M. A., R. A. Terry, R. E. Deriaz and G. E. Outen, J. Br. Grassld. Soc., 24: 238-243. 1969.

85）岡本全弘・広瀨可恒，目音会竍，43：499-505. 1972 .

86) Mowat, D. N., M. L. Kwatn and J.E. Winch, Can. J. Plant Sci., 49: 499-504. 1969.

87）岡本全弘・広瀬问恒，日畜会報，43：554-560. 1972.

88) Barker, J.T., G. Quicke, O. G. Bentley, R. R. Johnson and A. L. Moxon, J. Anim. Sci., 18: 655-662. 1959.

89）堀井 聡・阿部 亮, 畜試研報, 23: 89-94, 1970 .

90) Richards, G. N., Carbohydrates research in plants and animals, Miscellaneous paper, 12: 129-135. Landbouwhogeschool Wageningen, 1976.

91) Donefer, E., P. J. Nieman, E. W. Crampton and L. E. Lloyd, J. Dairy Sci., 46: 965-970. 1963.

92) Jones, D. I. H. and M. V. Hayward, J. Sci. Fd. Agric., 26: 711-718. 1975.

93) Clark, J. and J. Beard, Anim. Feed Science and Technology, 2: 153-159, 1977.

94) Rexen, B*, Anim. Feed Science and Technology, 2: 205-218. 1977.

95) MCQueen, R. and P. J, Van Soest, J. Dairy Sci, 58: 1482-1491. 1975.

96) Jones, D. I. H. and M. V. Hayward, J. Sci. Fd. Agric., 24: 1419-1426. 1973.

97) Hartley, R. D., E. C. Jones and J. S. Fenlon, J. Sci. Fd. Agric. 25: 947-954, 1974.

98) Balley, R. W. and D. I. H. Jones, N. Z. J. Agric. Res., 14: 847-857, 1971. 


\section{牛用飼料の栄養洒謤侕法}

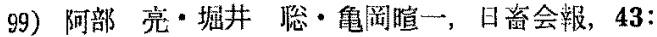
141-145. 1972.

100）阿部 完・堀井 聡, 日草誈, 20：16-21. 1974.

101) Jarrige, P., P. Thivand and C. Demarquilly, Proc. XI Int. Grassld. Cong. Queensland, Aus. tralia, p. 762-766. 1970.

102) Goto, I. and D. J. Minson, Anim. Feed Science and Technology, 2: 247-253. 1977.

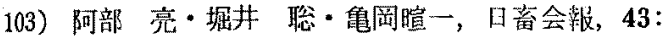
146-154. 1972 .

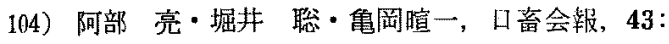
175-180. 1972 .

105）榑本 勲-正岡淑邦，日草㺊，24：1-9. 1978.

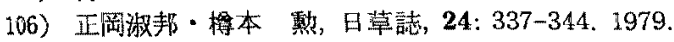

107) Guggol z, J., R. M. Saunders, G. O. Kehler and
T. J. Klophenstin, J. Anim. Sci., 33: 167-170. 1971.

108）李宗遠・阿部 亮，日畜会報，50：356-362. 1979.

109）阿部 亮・名久井忠, 日草誌, 25: 231-240. 1979.

110）阿部 究，日畜会垠，50：28-34，1979.

111) Hi Kon Oh and B. R. Baumgardt, J. Dairy Sci., 49: 850-855. 1966.

112) Tinnimit, P, and J. W. Thomas, J. Anim. Sci., 43: 1058-1065. 1976.

113) McLeod, M. N. and D. J. Minson, Anim. Feed Science and Technology, 1: 61-72, 1976.

114) Aerts, J. V., D. L. De Brabander, B. G. Cottny and F. X. Buysse, Anim. Feed Science and Technology, 2: 337-349. 1977.

115）堤 光明・阿部 孛, 日草誌, 23: 252-255. 1977. 